\title{
THE DIFFERENCE OF ENTREPRENEURIAL INTENTION BETWEEN ENTREPRENEUR AND NON-ENTREPRENEUR IN VIEW OF PERSONALITY
}

\author{
Rianda Elvinawanty \\ Ivory \\ Tjeng Ferra Dhammayanti \\ Elvina Yaputri \\ Mega Elfrida Sihombing \\ Inka Natalia \\ Fakultas Psikologi \\ Universitas Prima Indonesia \\ Jalan Sekip simpang Sikambing, Medan, Indonesia, 20111
}

\begin{abstract}
Entrepreneurs can help reduce unemployment and poverty in Indonesia. Someone who wants to be an entrepreneur is detectable from the entrepreneurial intention. Entrepreneurs and non-entrepreneurs (civil servants) have different personality characteristics. This study aimed to examine the relationship between personality and occupation with entrepreneurial intentions, and differences between entrepreneur and civil servants' entrepreneurial intentions. Research subjects were 100 entrepreneurs and 100 civil servants selected with purposive sampling method. Data collection method used Likert scales, namely personality scale (35 items, $\alpha=.923)$ and entrepreneurial intention scale (24 items, $\alpha=.899)$. Data analysis used analysis of covariance (ANCOVA) with SPSS 16 for Windows. Data analysis results showed personality was positively related to entrepreneurial intentions (Sig. $=.000<p=.05$ ), occupation affected entrepreneurial intentions (Sig. $=.000<p=.05)$, and the mean of entrepreneurial intentions of entrepreneurs' (73.67) was higher than civil servants'(71.58).
\end{abstract}

Keywords: occupation; personality; entrepreneurs; non-entrepreneurs; entrepreneurial intentions

\begin{abstract}
Abstrak---Wirausahawan dapat membantu mengurangi angka pengangguran dan kemiskinan di Indonesia. Seseorang yang hendak berwirausaha dapat dilihat dari intensi berwirausahanya. Wirausahawan dan non wirausahawan (Pegawai Negeri Sipil) memiliki karakteristik kepribadian yang berbeda. Penelitian ini bertujuan untuk mengkaji hubungan antara kepribadian dan pekerjaan dengan intensi berwirausaha, serta perbedaan intensi berwirausaha antara wirausahawan dan Pegawai Negeri Sipil (PNS). Subjek pada penelitian ini sebanyak 100 wirausahawan dan 100 PNS yang dipilih dengan metode purposive sampling. Metode pengumpulan data pada penelitian ini menggunakan skala Likert, yaitu skala kepribadian (35
\end{abstract}


item, $\alpha=0,923$ ) dan skala intensi berwirausaha (24 item, $\alpha=0,899)$. Analisis data menggunakan analisa kovarians (ANAKOVA) dengan bantuan SPSS 16 for Windows. Hasil analisa data menunjukkan bahwa kepribadian berhubungan positif dengan intensi berwirausaha (Sig. $=0,000$ $<\mathrm{p}=0,05$ ), pekerjaan mempengaruhi intensi berwirausaha (Sig. $=0,000<\mathrm{p}=0,05$ ), serta terdapat perbedaan mean intensi berwirausaha antara wirausahawan $(73,67)$ dengan PNS $(71,58)$, dimana intensi berwirausaha wirausahawan lebih tinggi daripada PNS.

Kata kunci: pekerjaan; kepribadian; wirausahawan; non-wirausahawan; intensi berwirausaha

\section{INTRODUCTION}

As a developing country, Indonesia has some concerning economic problems, including poverty and high unemployment. Indonesia's poverty rate, according to the data obtained by the Central Statistics Agency (BPS) as of March 2018, reached the number of 9.82\%, which was considered quite high. In addition, according to the data acquired from BPS in August 2018, the number of unemployed people in Indonesia reached $5.34 \%$ of the total population included in the workforce, and only $3 \%$ of the unemployed were preparing for their own businesses, in other words, starting an entrepreneurship.

This figure was relatively insignificant, considering that entrepreneurs play an important role in reducing poverty. According to Riyanti (as cited in Sabela, Ariati, \& Setyawan, 2014), someone who is able to find opportunities, build, manage, and institutionalize his business is called an entrepreneur. Uno (as cited in Sabela, Ariati, \& Setyawan, 2014) stated that entrepreneurship contributes to most of the tax that the government receives, which is $70 \%$ of the Indonesian State Budget, so that the more entrepreneurs, the higher the state revenue and economic growth in Indonesia. In addition, an entrepreneur can also provide employment to the community without having to depend on other parties. To reduce unemployment and poverty, Indonesia needs more individuals who can support entrepreneurship activities, which was proposed by Hisrich, Peter and Sheperd (as cited in Hamali, 2016) as a dynamic process in creating additional wealth.

Someone who wants to be an entrepreneur can be seen from the entrepreneurial intention. 
Bird (as cited in Brännback \& Carsrud, 2018) defined entrepreneurial intentions as the state of mind that directs and guides individual's actions towards the development and implementation of new business concepts. According to BPS data in August 2017, only 22.81\% of the citizens in Medan were business owners, while up to $61.99 \%$ of the people were employees. The low entrepreneurial intention was influenced by the idea that entrepreneurs have an uncertain income, there is too much risk, and because they do not have enough fund. But besides the influence of the thoughts above, one's personality can also affect one's intentions in running their own business.

Schumpeter (as cited in Karabulut, 2016) stated that entrepreneurs need to take risks when making decisions. Risk-taking propensity is a personality that shows someone's willingness and tendency to take risks, and according to Al-Karim and Handoyo (2013), it is essential for an entrepreneur, since not everyone is ready to bear the risk when taking opportunities.

In addition, according to Wood and Teoh and Foo (as cited in Al-Karim \& Handoyo, 2013), entrepreneurs need to have ambiguity tolerance, which is the ability to maintain decisions that have been made despite being in an uncertain situation, and find this situation interesting. Koh and Schere's (as cited in Al-Karim \& Handoyo, 2013) research studies showed that entrepreneurs' ambiguity tolerance is higher than non-entrepreneurs'.

During the first time starting a business, entrepreneurs also need high self-confidence, so it can be concluded that entrepreneurs have high self-confidence. Studies conducted by Baum and Locke, and Koh (as cited in Al-Karim \& Handoyo, 2013) showed that entrepreneurs have a higher level of self-confidence than others.

To run a business, social skills are also important. Friedman and Schustack (as cited in Novitaloka \& Nurtjahjanti, 2015) stated that someone who has an extraversion personality is usually full of enthusiasm, dominant, friendly, and communicative. According to the research of Zhao and Seibert (as cited in Leutner, Ahmetoglu, Akhtar, \& Chamorro-Premuzic, 2014), entrepreneurs' extraversion personality is higher than non-entrepreneurs'.

To start an innovative business, surely you need a person with an innovative personality. Thomas and Mueller (as cited in Al-Karim \& Handoyo, 2013) stated that the terms innovation and entrepreneur are inseparable and research showed that entrepreneurs are more innovative 
than non-entrepreneurs.

According to McClelland (as cited in Al-Karim \& Handoyo, 2013), individuals with need of achievements try to excel and achieve progress. This is what drives an entrepreneur to start his own business, so it can be said that the high need for achievement is a personality characteristic possessed by entrepreneurs. Research studies of Robinson et al. and Steward et al. (as cited in AlKarim \& Handoyo, 2013) showed that the need for achievement of entrepreneurs is higher than non-entrepreneurs.

An entrepreneur must be keen to see the opportunities that exist, and make it as a chance to start their business. According to Kirzner (as cited in Karabulut, 2016), entrepreneurial alertness is the ability to realize opportunities that have been neglected by others, so it is the main characteristic of an entrepreneur.

Proactive personality was defined by Bateman and Crant (as cited in Delle \& Amadu, 2015) as a construct that identify differences between individuals in terms of how they take action to influence their environment. Delle and Amadu's (2015) research results showed that proactive personality is a direct predictor of entrepreneurial intentions in entrepreneurs.

According to Shane et al. (as cited in Al-Karim \& Handoyo, 2013), entrepreneurs prefer to take responsibility for their lives rather than living from the business of others, which encourages them to start their own businesses, so entrepreneurs need to have high self efficiency / freedom.

Entrepreneurs choose to take responsibility for themselves, corresponding to the characteristics of internal locus of control. Mueller and Thomas's (as cited in Al-Karim \& Handoyo, 2013) research proved that these characteristics can distinguish entrepreneurs from non-entrepreneurs.

Based on the description above, the questions appeared: (1) Do personality characteristics determine entrepreneurial intention? (2) Are there differences in entrepreneurial intentions between entrepreneurs and non-entrepreneurs?

The purpose of this study was to analyze whether personality characteristics affect one's entrepreneurial intentions, and to compare entrepreneurial intentions between entrepreneurs and non-entrepreneurs. 
This research was conducted with the following hypotheses: (1) H1: There is a positive relationship between personality characteristics and occupation with entrepreneurial intentions, and (2) H2: There are differences in entrepreneurial intentions between entrepreneurs and nonentrepreneurs.

\section{METHODS}

\section{Participant}

This research was a quantitative research, in which the population studied were the entrepreneurs and civil servants in Medan. The samples in this study were 100 entrepreneurs and 100 civil servants. The sampling technique used was purposive sampling technique, which according to Yusuf (as cited in Irkhamiyati, 2017) is a technique that is first based on certain considerations. In this case, the determined consideration was that the entrepreneurs were domiciled in Medan and that the civil servants worked purely as civil servants without having side jobs or other businesses and were domiciled in the city of Medan.

\section{Design}

The independent variable was occupation, namely as entrepreneur or civil servant. The dependent variable in this study was the entrepreneurial intention. The covariate variable in this study was personality. According to Trochim (as cited in Purnamayanti, Suardana, \& Selamet, 2019), a covariate variable is a variable used to reduce noise in data analysis caused by variables other than the variables studied, so that the effects of the variables studied can be seen clearly.

\section{Procedure}

The data collection methods used in this study were scales that had been tested for its validity and reliability. According to Azwar (2016), validity is the extent to which a measuring instrument (test) can precisely and accurately perform its measurement function. Reliability, according to Azwar (as cited in Suharsono \& Istiqomah, 2014), is the consistency of a measuring instruments. The scales used were a questionnaire to measure personality, consisting of need for 
achievement, risk taking propensity, internal locus of control, ambiguity tolerance, selfconfidence, creativity / innovation, self sufficiency / freedom, extraversion personality, proactive personality, and entrepreneurial alertness (35 items, $\alpha=.923$ ), as well as a questionnaire to measure entrepreneurial intentions ( 24 items, $\alpha=.899$ ). The statements that had been compiled in the questionnaire were then measured by using Likert scale, which according to Sugiyono (2018) is used to measure people's attitudes, opinions and perceptions about the phenomena that occurred.

\section{Analysis Technique}

The analysis of the data in this study used the analysis technique named Analysis of Covariance (Ancova), which according to Rutherford and Vidakovic (as cited in Mangalathu, Jeon, \& DesRoches, 2015) is a general linear model in the form of a combination of ANOVA (Analysis of Variance) and regression analysis. The data was analyzed with the help of SPSS 16 for Windows.

\section{RESULTS}

Before conducting hypothesis test, assumption tests were first performed to determine whether there was any deviation in the data obtained from the data collection tool. The assumption test used in this study, the Ancova test, according to McLean (1979) are a normality test, a homogeneity test, a linearity test, a correlation test, and a homogeneity of regression slopes test.

\section{Normality Test}

Table 1. Normality Test Result

\begin{tabular}{cccc}
\hline Variable & K-SZ & P & Description \\
\hline Personality & 1.139 & 0.149 & Normal distribution $(\mathrm{P}>0.05)$ \\
Entrepreneurial Intention & 1.005 & 0.265 & Normal distribution $(\mathrm{P}>0.05)$ \\
\hline \multicolumn{2}{l}{ Normality test is carried out to find out whether each research variable in a research is }
\end{tabular}


normally distributed. The normality test used was the Kolmogorov-Smirnov Test (K-SZ) test. The data is said to be normally distributed if $\mathrm{p}>.05$. As shown in Table 1, the K-SZ value of the personality variable for the 2-tailed test was 1.139 with Sig. $=.149$, while this study used a 1 tailed hypothesis, so the used result was 1-tailed test of .0745 ( $\mathrm{p}>.05$ ) meaning that the personality scores were normally distributed. The entrepreneurial intention variable showed the $\mathrm{K}-\mathrm{SZ}$ value of 1.005 with Sig. = .265 for the 2-tailed test, while this study used a 1-way hypothesis, so the result used was 1-tailed test of .1325 $(\mathrm{p}>.05)$ meaning that the intention scores were normally distributed. Based on these results, the data on the variables personality and intentions were normally distributed.

\section{Homogeneity Test}

Table 2. Homogeneity Test Result

\begin{tabular}{ccc}
\hline Variable & P & Description \\
\hline Personality & 0.128 & Homogeneous $(\mathrm{P}>0.05)$ \\
Entrepreneurial Intention & & \\
\hline
\end{tabular}

Homogeneity test is used to determine whether several population variants are the same or not. As a testing criterion, if the significance value $>.05$, it can be concluded that the variants of 2 or more data groups are the same. Based on the Homogeneity of Variances table (see Table 2), it was known that the value of Sig. $=.128>$ from the significant level of .05 , thus the groups tested were homogeneous.

\section{Linearity Test}

Table 3. Linearity Test Result

\begin{tabular}{ccc}
\hline Variable & P & Description \\
\hline Personality & 0.000 & Linear $(\mathrm{P}<0.05)$ \\
Entrepreneurial Intention & &
\end{tabular}

Linearity test is used to determine whether the distribution of research data, namely personality and intention variables have a linear relationship. Personality and intention variables 
are said to have a linear relationship if $p<.05$. This can be seen from Table 3 , that the $p$ value obtained, namely .000 , is $\mathrm{p}<.05$, so it can be concluded that the two variables had a linear relationship.

\section{Correlation Test}

Table 4. Correlation Test Result

\begin{tabular}{cccc}
\hline Variable & R & P & Description \\
\hline Personality & 0.706 & 0.000 & Significant correlation \\
Entrepreneurial Intention & & & $(\mathrm{P}<0.05)$ \\
\hline
\end{tabular}

Correlation test is used to find the relationship between two quantitative variables. One of the requirements before conducting an Ancova test is that there is a significant correlation between the covariate and the dependent variable. The result as shown in Table 4 showed that personality correlated significantly with entrepreneurial intention $(r=.706)$ with Sig. $=.000<p$ $=.05$, so that personality can be included as a covariate.

\section{Homogeneity of Regression Slopes Test}

Table 5. Homogeneity of Regression Slopes Test Result

\begin{tabular}{ccc}
\hline Variable & P & Description \\
\hline Occupation*personality & 0.149 & Significant ( P > 0.05)
\end{tabular}

Homogeneity of Regression Slope test which is performed to test the slope of the regression line between groups, is a prerequisite test before an Ancova test is performed, with the condition that there is no interaction between the covariate and the independent variables. In Table 5, the results showed that the significance value between occupation * personality $=.149>$ $\mathrm{p}=.05$. This means that there was no interaction between subjects whose occupation were entrepreneurs and subjects whose occupation were civil servants, so the Ancova test can be conducted.

After all of the assumption tests were accepted, a hypothesis test was conducted. The hypotheses in this study are that there is a positive relationship between personality and entrepreneurial intentions and there are differences in entrepreneurial intentions between 
entrepreneurs and civil servants. The hypotheses were tested using the Ancova test.

\section{ANCOVA Test}

Table 6. Ancova Test Result

\begin{tabular}{ccc}
\hline Variable & P & Description \\
\hline Personality & 0.000 & $\mathrm{P}<0.05$ (significant) \\
Occupation & 0.000 & $\mathrm{P}<0.05$ (significant)
\end{tabular}

The result of the analysis of personality variable as shown in Table 6 was Sig. $=.000<p$ $=.05$, thus personality influenced entrepreneurial intention significantly. The result of the analysis of occupation variable was Sig. $=.000<\mathrm{p}=.05$, thus occupation significantly influenced entrepreneurial intention.

\section{Mean Table}

Table 7. Mean Table

\begin{tabular}{ll}
\hline Occupation & Mean \\
\hline Entrepreneur & 73.67 \\
Civil Servants & 71.58
\end{tabular}

As shown in Table 7, the result of entrepreneurs' entrepreneurial intentions with a mean value of 73.67 and civil servants' entrepreneurial intentions with a mean value of 71.58 showed that entrepreneurs had higher entrepreneurial intentions than civil servants.

\section{DISCUSSION}

The result of the study on 100 entrepreneurs and 100 civil servants who were the research subjects showed that there was a significant positive relationship between personality and entrepreneurial intention, with Sig. $=.000<\mathrm{p}=.05$, and there was a positive relationship between occupation and entrepreneurial intention, with Sig. $=.000<\mathrm{p}=.05$. In addition, entrepreneurs' entrepreneurial intention was higher than that of civil servants, with the mean 
value of entrepreneurial intentions on entrepreneurs was 73.67 and civil servants was 71.58.

Someone is considered to have a good risk taking propensity when he can show willingness and tendency in taking risks related to starting a new business, so that the entrepreneurial intention is high. Someone has good ambiguity tolerance when he is able to make decisions and keep them under uncertainty, which is needed during entrepreneurship, then the entrepreneurial intention is high. A person has high self confidence when he has the confidence needed to build his own business, then the entrepreneurial intention is also high. Someone has good extraversion personality when he has enthusiasm and can communicate well, making it easier to establish relationships related to his business, then the entrepreneurial intention is high. Someone has a high need for achievement when he has a great desire to achieve progress, one of which is in terms of gaining success in the business he built, then the entrepreneurial intention is also high. Someone has a good entrepreneurial alertness when he is aware of the opportunities, especially opportunities related to business, then the entrepreneurial intention is high. A person has a good proactive personality when he can be responsible for making decisions, which of course is needed in establishing a business, so the entrepreneurial intention is high. A person has high self sufficiency / freedom where he wants to have control over what he does, not depending on other people's commands, so he also has high entrepreneurial intention. Someone has good internal locus of control when he knows that everything that happened is the result of his own actions and not determined by others, so he strives for success, then the entrepreneurial intention is high. Someone who has good innovation is very crucial in entrepreneurship, because innovation is needed to support a business, then the entrepreneurial intention is also high.

The results of this study were in accordance with the results of research by Al-Karim and Handoyo (2013) and Bezzina (2010) which showed that need for achievement, risk taking propensity, internal locus of control, ambiguity tolerance, self-confidence, creativity / innovation, and self sufficiency / freedom are personality characteristics that exist in an entrepreneur. In addition, the research results conducted by Novitaloka and Nurtjahjanti (2015) also stated that extraversion personality has a positive and significant influence on entrepreneurial intentions. The study results of Permatasari and Agustina (2018) showed that need for achievement, risk tolerance, and entrepreneurial alertness influenced entrepreneurial intentions. In addition, 
researches by Rizki and Megawati (2019) and Arnyaningtyas and Palupiningtyas (2019) showed that proactive personality has a positive effect on entrepreneurial intention. The research result of Adnyana and Purnami (2016) showes that locus of control has a significant effect on entrepreneurial intention. The research of Ermawati, Soesilowati, and Prasetyo (2017) showed that there is an influence of need for achievement and locus of control on entrepreneurial intention. Yusuf and Hamzah (2016) conducted a research that showed self-confidence has a positive effect on entrepreneurial intention.

\section{CONCLUSION AND SUGGESTION}

\section{Conclusion}

Based on the explanation above it can be concluded that the results of previous studies stated that there is a relationship between risk taking propensity, ambiguity tolerance, selfconfidence, need for achievement, proactive, self sufficiency / freedom, internal locus of control, entrepreneurial alertness, innovative, extraversion with entrepreneurial intention. Personality has a positive relationship with entrepreneurial intention, according to the results that had been carried out in this study. There was also a significant difference in entrepreneurial intention between entrepreneurs and non-entrepreneurs.

\section{Suggestion}

For future research, researchers need to consider the age of the research subjects, and whether the research subjects will retire soon. In this research, most of the subjects who are Civil Servants (PNS) were older aged seniors nearing their retirement period. The closer the subjects were to retirement, the higher their entrepreneurial intentions were, because they wanted to have something to do to fill their time with after retiring, and to have extra income. Beside that, future researchers need to consider other variables which may have impact on the research results, such as gender, duration of working, work position, income, and so on. 


\section{REFERENCES}

Adnyana, I., \& Purnami, N. (2016). Pengaruh Pendidikan Kewirausahaan, Self Efficacy Dan Locus of Control Pada Niat Berwirausaha. E-Jurnal Manajemen Universitas Udayana, 5(2), 1160-1188 . https://ojs.unud.ac.id/index.php/Manajemen/article/view/16350/12318

Al-Karim, A. Y. S., \& Handoyo, S. (2013). Kepribadian entrepreneur pada mahasiswa universitas airlangga. Jurnal Psikologi Industri Dan Organisasi, 2, 33-43. http://journal.unair.ac.id/download-fullpapers-jpiod2396b90ae2full.pdf

Arnyaningtyas, A. T., \& Palupiningtyas, D. (2019). Pengaruh kepribadian proaktif terhadap intensi kewirausahaan mahasiswa: Pendidikan kewirausahaan sebagai variabel moderasi. Matrik. Jurnal Manajemen, Strategi Bisnis Dan Kewirausahaan, 13, 15-25. https://doi.org/10.24843/MATRIK:JMBK.2019.v13.i01.p02

Azwar, S. (2016). Metode penelitian. Yogyakarta: Pustaka Pelajar.

Brännback, M., \& Carsrud, A. L. (2018). A research agenda for entrepreneurial cognition and intention. In A Research Agenda for Entrepreneurial Cognition and Intention. Edward Elgar Publishing. https://doi.org/10.4337/9781784716813

Delle, E., \& Amadu, I. M. (2015). Proactive personality and entrepreneurial intention: Employment status and student level as moderators. International Journal of Small Business and Entrepreneurship Research, 3, 1-13. http://www.eajournals.org/wpcontent/uploads/Proactive-Personality-and-Entrepreneurial-Intention-Employment-Statusand-Student-Level-as-Moderators.pdf

Ermawati, N., Soesilowati, E., \& Prasetyo, P. E. (2017). Pengaruh Need for Achivment Dan Locus of Control Terhadap Intensi Berwirausaha Melalui Sikap Siswa Kelas Xii Smk Negeri Se Kota Semarang. Journal of Economic Education, 6(1), 66-74. https://doi.org/10.15294/jeec.v6i1.14704 
Psikologi Prima

Hamali, A. Y. (2016). Pemahaman Strategi Bisnis \& Kewirausahaan. Prenadamedia Group.

Irkhamiyati, I. (2017). Evaluasi Persiapan Perpustakaan Stikes 'Aisyiyah Yogyakarta Dalam Membangun Perpustakaan Digital. Berkala Ilmu Perpustakaan Dan Informasi, 13(1), 3746. https://doi.org/10.22146/bip.26086

Karabulut, A. T. (2016). Personality Traits on Entrepreneurial Intention. Procedia - Social and Behavioral Sciences, 229, 12-21. https://doi.org/10.1016/j.sbspro.2016.07.109

Leutner, F., Ahmetoglu, G., Akhtar, R., \& Chamorro-Premuzic, T. (2014). The relationship between the entrepreneurial personality and the Big Five personality traits. Personality and Individual Differences, 63, 58-63. https://doi.org/10.1016/j.paid.2014.01.042

Mangalathu, S., Jeon, J., Desroches, R., \& Padgett, J. (2015). Analysis of Covariance to Capture the Importance of Bridge Attributes on the Probabilistic Seismic Demand Model. PCEE, 16, 1-8. https://www.aees.org.au/wpcontent/uploads/2015/12/Paper_16.pdf

McLean, J. E. (1979). The care and feeding of ancova. In Statistical Package for the Social Science (pp. 1-30). https://files.eric.ed.gov/fulltext/ED191867.pdf

Novitaloka, M., \& Nurtjahjanti, H. (2015). Hubungan Antara Tipe Kepribadian Ekstraversi Dengan Intensi Berwirausaha Pada Pegawai Dinas Sosial Provinsi Jawa Tengah. Empati: Jurnal Karya Ilmiah Sl Undip, 4(1), 111-115. https://ejournal3.undip.ac.id/index.php/empati/article/view/13126/12684

Permatasari, A., \& Agustina, A. (2018). Entrepreneurial Behaviour Among Undergraduate Business, Social and Engineering Students: a Case Study of a Private Indonesian University. Jurnal Manajemen Indonesia, 18(2), 94-104. https://doi.org/10.25124/jmi.v18i2.1172 
Purnamayanti, D. A. D., Suardana, I. N., \& Selamet, K. (2019). Studi Komparasi Model Pembelajaran Kooperatif Tipe Teams Games Tournament Dan Student Teams Achievement Division Ditinjau Dari Hasil Belajar Ipa Siswa. Jurnal Pendidikan Dan Pembelajaran Sains Indonesia (JPPSI), 2(1), 23. https://doi.org/10.23887/jppsi.v2i1.17221

Rizki, Q. G., \& Megawati. (2019). Pengaruh Faktor Dukungan Universitas Dan Kepribadian Proaktif Terhadap Intensi Berwirausaha Pada Mahasiswa S1 Fakultas Ekonomi Dan Bisnis Universitas Syiah Kuala. Jurnal Ilmiah Mahasiswa Ekonomi Manajemen, 4(1), 345-359. http://www.jim.unsyiah.ac.id/EKM/article/viewFile/10019/4548

Sabela, O. I., Ariati, J., \& Setyawan, I. (2015). Ketangguhan Mahasiswa Yang Berwirausaha: Studi Kasus. Jurnal Psikologi Undip, 13(2), 170-189. https://doi.org/10.14710/jpu.13.2.170189

Suharsono, Y., \& Istiqomah. (2014). Validitas Dan Reliabilitas Skala Self-Efficacy. Jurnal $\begin{array}{llll}\text { Ilmiah Psikologi } & \text { Terapan, }\end{array}$ http://ejournal.umm.ac.id/index.php/jipt/article/view/1776

Sugiyono. (2018). Metodologi penelitian kuantitatif, kualitatif, dan $r \& d . P e n e r b i t$ Alfabeta.

Yusuf, A. A., \& Hamzah, A. (2016). Pengaruh Kepercayaan Diri Dan Semangat Kewirausahaan Terhadap Minat Menjadi Wirausaha. Al-Amwal, 8(2), 481-490. https://syekhnurjati.ac.id/jurnal/index.php/amwal/article/view/1370 